\title{
Evidence for dependency of bacterial growth on enzymatic hydrolysis of particulate organic matter in the mesopelagic ocean
}

\author{
H.-G. Hoppe ${ }^{1}$, H. Ducklow ${ }^{2}$, B. Karrasch ${ }^{1}$ \\ 'Institut für Meereskunde, Düsternbrooker Weg 20, W-2300 Kiel 1, Germany \\ ${ }^{2}$ Horn Point Environmental Laboratory, PO Box 775, Cambridge, Maryland 21613, USA
}

\begin{abstract}
Organic material entering the oceanic mesopelagic zone may either reenter the euphotic zone or settle into deeper waters. Therefore it is important to know about mechanisms and efficiency of substrate conversion in this water layer. Bacterial biomass, bacteria secondary production (BSP), extracellular peptidase activity (EPA) and particulate organic nitrogen (PON) were measured in vertical profiles of the North Atlantic $\left(46^{\circ} \mathrm{N} 18^{\circ} \mathrm{W} ; 57^{\circ} \mathrm{N} 23^{\circ} \mathrm{W}\right.$ ) during the Joint Global Ocean Flux Study (JGOFS) cruise in May 1989. The magnitude of these parameters decreased differently with depth. The strongest decreases were observed for bacterial production $\left({ }^{3} \mathrm{H}\right.$-thymidine incorporation) and peptide turnover (using the substrate analog leucine-methylcoumarinylamide). Bacterial biomass and peptidase potential activity were not reduced as much in the mesopelagic zone. Peptidase potential per unit cell biomass of mesopelagic bacteria was 2 to 3 times higher than that of bacteria in surface water. Nevertheless bacterial growth at depth was slow, due to slow actual hydrolysis. Values of theoretical PON hydrolysis were calculated from PON measurements and protein hydrolysis rates. These corresponded well to bacterial production rates, and the degree of correspondence increased from a factor of 0.63 (PON hydrolysis/BSP) in the mixed surface layer to 0.87 in the mesopelagic zone. Thus we hypothesized an effective coupling between particle hydrolysis and uptake of hydrolysate by bacteria, which depletes the deeper water of easily degradable substrates as hydrolysates usually are. The low enzymatic PON turnover rate of $0.04 \mathrm{~d}^{-1}$ in the subeuphotic zone suggests that residence time of particles within a depth stratum may be important for its contribution to export, storage and recycling of organic matter.
\end{abstract}

\section{INTRODUCTION}

The vertical flux of particulate organic matter (POM) has been recognized as the most important process of organic matter supply to the ocean's aphotic mesopelagic zone (Gordon 1970b, McCave 1975, Suess 1980. Sasaki \& Nishizawa 1981, Lee \& Cronin 1982, Ducklow et al. 1985, Cho \& Azam 1988, Karl et al. 1988). Recently it has been stated by Cho \& Azam (1988), that bacteria rather than the particle-feeding zooplankton are the principal mediators of particle decomposition. Sedimenting materials retained and stored in the mesopelagic zone by bacterial hydrolysis provide a basis for life in this oceanic compartment. They are prevented from sinking to the deep sea and thus contribute to more rapid nutrient recycling. Particles, in the sense as the term is used here, also include fine grain and delicate mucoid materials which may often escape microscopic observation. In particular, slowly sinking particulate matter may be a preferred source of nutrients for mesopelagic bacteria (Karl et al. 1988). Increasing bacterial colonization of slowly sinking POM in the deep (Alldredge \& Youngbluth 1985) suggests that attached bacteria and probably also bacteria clustering around the particles (Mitchell et al. 1985, Alldredge \& Cohen 1987, Cho \& Azam 1988) are responsible for POM dissolution, but the biochemistry of this process is not well understood. Changes observed in the $\mathrm{C}: \mathrm{N}$ ratio of sedimenting organic particles suggest preferential hydrolysis of the particulate organic nitrogen (PON) component of POM (Gordon 1971, Lee \& Cronin 1982). 
We now provide more direct evidence for coupling of bacterial growth and PON hydrolysis in the oceanic interior, using newly developed fluorometric techniques for the measurement of extracelluar enzyme activity (Hoppe 1983, Somville \& Billen 1983, Hoppe 1986, Hoppe et al. 1988). Correspondence between bacterial growth and the PON hydrolysis rate is relatively poor in the euphotic zone, because labile substrates ready for incorporation (Jumars et al. 1989, Fasham et al. 1990) are present. In the aphotic mesopelagic zone the dependency of bacterial growth on the theoretical PON hydrolysis rate is evident. These findings are supported by observations that extracellular peptidase potentials of individual bacterial cells increase with water depth. Results, obtained from the Joint Global Ocean Flux Pilot Study (JGOFS), 1989, are presented here in a scheme which emphasizes the predominant pathways of bacterial PON/DON conversion in the ocean. Investigations in the North Atlantic were made at depths between 100 and $200 \mathrm{~m}$ (and in one case down to $500 \mathrm{~m}$ ) which may be defined as the 'upper mesopelagic zone'.

\section{METHODS}

Water samples for bacterial activity and chemical analysis were taken during the JGOFS cruise in the North Atlantic at 2 drift-stations between the Azores and Iceland $\left(46^{\circ} \mathrm{N}, 18^{\circ} \mathrm{W} ; 57^{\circ} \mathrm{N}, 23^{\circ} \mathrm{W}\right)$ in May 1989. The methods used were intercalibrated between the participating American, English and German groups before the cruise. Sampling of depth profiles was arranged according to in situ fluorescence characteristics in the photic zone and to standard depths beneath.

Bacterial abundance and biomass were determined by epifluorescence microscopy (Hobbie et al. 1977, Zimmermann 1977). Extracellular peptidase activities (EPA) of bacteria were measured using the fluorogenic substrate analog leu-MCA (leucine-methylcoumarinylamide) (Hoppe et al. 1988), which competes well with easily degradable natural peptides (Hoppe 1986, Chróst 1990). For the calculation of the peptide hydrolysis rate $\left(H_{\mathrm{r}}, \% \mathrm{~d}^{-1}\right)$ and the maximum velocity of hydrolysis $\left(V_{\mathrm{m}}, \mu \mathrm{g} \mathrm{Cl}^{-1} \mathrm{~h}^{-1}\right)$, substrate analog was supplied to the sample water at final concentrations of $0.3 \mu \mathrm{M} \mathrm{l}^{-1}$ and $175 \mu \mathrm{M} \mathrm{l}^{-1}$. Taking into account the observed PON concentrations (see Fig. 2), applied substrate analog concentrations are assumed to be appropriate for the calculation of the desired key parameters $\left(V_{\mathrm{m}}, H_{\mathrm{r}}\right.$ ) at all sampling depths. Triplicates of subsamples were incubated for 4 to $6 \mathrm{~h}$ at in situ temperature; deep water samples were occasionally incubated up to $24 \mathrm{~h}$. A Kontron SFM 25 fluorometer was used for fluorescent reading of substrate analog hydrolysis at
$380 \mathrm{~nm}$ excitation and $440 \mathrm{~nm}$ emission. Fluorescences of standard AMC (7-amino-4-methylcoumarin) solutions were used for calibration. This method allowed for the first time reliable measurements of peptidase activity down to about $700 \mathrm{~m}$.

Bacterial secondary production (BSP) was determined by $\left[{ }^{3} \mathrm{H}\right.$-methyl]-thymidine (TdR) incorporation (Fuhrman \& Azam 1982), using $2 \times 10^{18}$ cells produced $\mathrm{mol}^{-1} \mathrm{TdR}$ for calculation of bacteria production (JGOFS 1990b), $20 \mathrm{fg} \mathrm{C} \mathrm{cell}{ }^{-1}$ for biomass conversion and 3.7 for bacterial $\mathrm{C} / \mathrm{N}$ relationship (Lee \& Fuhrman 1987). Experiments were run at an experimentally verified thymidine saturation concentration of $5 \mathrm{nM} \mathrm{l}^{-1}$. BSP was calculated from 3 replicates and expressed in terms of thymidine incorporation ( $p m o l \mathrm{l}^{-1} \mathrm{~h}^{-1}$ ) or nitrogen production $\left(\mu \mathrm{g} \mathrm{N} \mathrm{^{-1 }} \mathrm{d}^{-1}\right.$ ). Particulate organic nitrogen (PON) was measured in a CHN-Analyser (Perkin Elmer) after collection on glassfiber filters. The data base of the first example presented here was exclusively obtained from the German group on RV 'Meteor', in the second example combined results of the American group (RV 'Atlantis II') and the German group were combined. Also included are results of the American North Atlantic Bloom Experiment (NABE) (Ducklow et al. 1993) from the same region (Fig. 1) and dates which provide additional proof for our hypotheses.

\section{RESULTS}

The data sets obtained were analysed in respect to 2 hypotheses pertinent to mesopelagic carbon cycling: (1) bacterial production and the dissolved organic matter (DOM) pool in the mesopelagic zone of the ocean are based on (non-living) particulate organic matter (POM) and regulated by extracellular peptidase activity (EPA); and (2) slow growth of bacteria in the mesopelagic with minimal fluxes of labile DOM does not necessarily imply slow reaction towards changing conditions. At least part of the bacterial community is opportunistic and able to react rapidly to pulses of organic matter inputs from the euphotic zone.

An example of a depth profile from $57^{\circ} \mathrm{N}, 23^{\circ} \mathrm{W}$ (Table 1) shows the expected decrease of all measurements with depth (Rosso \& Azam 1987). The rate of decrease, which differs among parameters, provides the basis of our interpretation.

There was a sharp zonation of bacterial production with high values above the thermocline $(20 \mathrm{~m})$ and very low values below (Table 1). Decreases of peptidase activity parameters ( $V_{\mathrm{m}}$ and $H_{\mathrm{r}}$ ) and of bacterial biomass from the surface down to the compensation depth $(80 \mathrm{~m})$ were very similar, however, they differed considerably at greater depths. The highest ratio of activity in the upper layer to activity at $300 \mathrm{~m}$ and 
Table 1. Bacterial biomass and activity measurements at a station in the North Atlantic Ocean $\left(57^{\circ} \mathrm{N}, 23^{\circ} \mathrm{W}\right)$. Ratios of surface $(5 \mathrm{~m})$ to depth values in parentheses. Thermocline between 20 and $40 \mathrm{~m}$ depth. $V_{\text {m }}$ : maximum velocity peptidase activity, as nneasured by hydrolysis of the model substrate Leu-MCA (leucine-methylcoumarinylamide) at $175 \mu \mathrm{Ml}^{-1}$. $\mathrm{H}_{\mathrm{r}}$ : rate of hydrolysis $\left(\% \mathrm{~d}^{-1}\right)$ of the model substrate Leu-MCA at $0.3 \mu \mathrm{Ml}^{-1}$ Because the model substrate is competitively inhibited by natural peptides and the affinity of peptidases to natural peptides is roughly the same in comparison to the model substrate, $H_{\mathrm{r}}$ approximates the hydrolysis rate of the natural concentration of peptides

\begin{tabular}{|c|c|c|c|c|}
\hline \multirow{2}{*}{$\begin{array}{l}\text { Depth } \\
\text { (m) }\end{array}$} & \multirow{2}{*}{$\begin{array}{l}\text { Bacterial biomass } \\
\qquad\left(\mu \mathrm{g} \mathrm{C}^{-1}\right)\end{array}$} & \multicolumn{2}{|c|}{ Peptidase activity } & \multirow{2}{*}{$\begin{array}{c}\text { Bacterial production } \\
\text { (thymidine incorporation, } \\
\text { pmol } \mathrm{l}^{-1} \mathrm{~h}^{-1} \text { ) }\end{array}$} \\
\hline & & $V_{\mathrm{m}}\left(\mu \mathrm{g} C \mathrm{l}^{-1} \mathrm{~h}^{-1}\right)$ & $H_{r}\left(\% d^{-1}\right)$ & \\
\hline 5 & 27.1 & 4.2 & 14.1 & 4.4 \\
\hline 10 & $24.8(1.1)$ & $4.1(1.0)$ & $15.7(0.9)$ & $2.5(1.8)$ \\
\hline 20 & $27.9(0.9)$ & $3.2(1.3)$ & $11.3(1.3)$ & $2.3(1.9)$ \\
\hline 40 & $17.8(1.5)$ & $2.2(1.9)$ & $7.5(1.9)$ & $0.6(7.3)$ \\
\hline 80 & $12.0(2.3)$ & $1.5(2.7)$ & $5.9(2.4)$ & $0.5(8.6)$ \\
\hline 300 & $4.0(6.8)$ & $1.1(4.0)$ & $1.0(13.9)$ & $0.4(11.0)$ \\
\hline 500 & $2.8(9.7)$ & $0.9(4.3)$ & $0.6(23.9)$ & $0.3(14.7)$ \\
\hline
\end{tabular}

$500 \mathrm{~m}$ was found for $H_{\mathrm{r}}$, reflecting the recalcitrance of organic materials towards bacterial hydrolysis at these depths. In contrast, $V_{\mathrm{m}}$ of peptidases decreased much less. Bacterial biomass declined more rapidly than peptidase $V_{\mathrm{m}}$ at these depths, implying that bacteria in the mesopelagial rapidly attained high hydroloytic activity after addition of a relatively easily degradable substance (here, the substrate analog Leu-MCA). Peptidase potential $\left(V_{\mathrm{m}}\right)$ per unit cell biomass of mesopelagic bacteria was about 2 to 3 times higher than that of bacteria in surface water. High hydrolytic capacities in the mesopelagial would be necessary for survival in deep water. Nevertheless, actual hydrolysis rates $\left(H_{\mathrm{I}}\right)$ as well as bacterial production were low, probably due to the lack of easily degradable organic materials in these water depths (Gordon 1970a). Measured hydrolysis rates of proteinaceous matter should thus be related both to PON stocks available for hydrolysis and bacterial production. Another depth

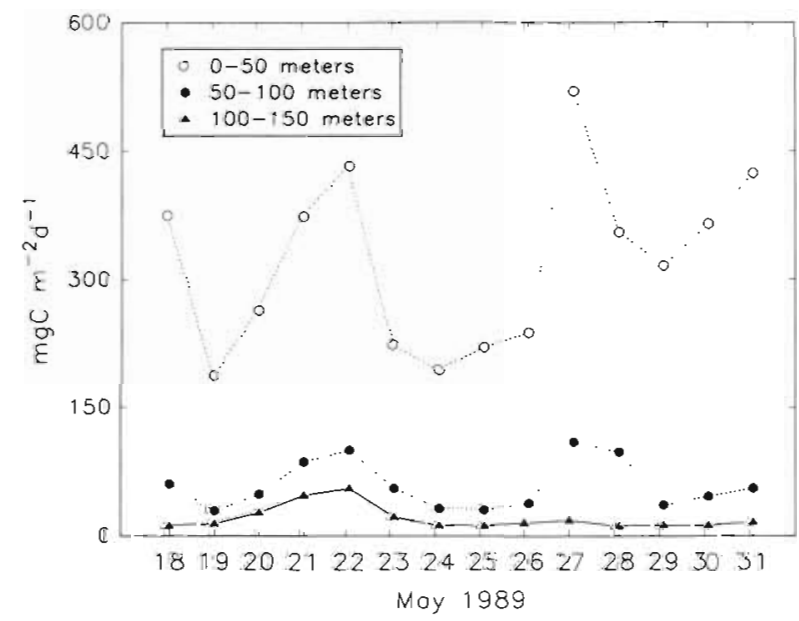

Fig. 1. Depth-integrated bacterial production in the euphotic zone and the upper mesopelagic zone $\left(47^{\circ} \mathrm{N}, 20^{\circ} \mathrm{W}\right)$ during a phytoplankton spring bloom in May 1989 profile showing the same clear cut trends was obtained from $46^{\circ} \mathrm{N} 18^{\circ} \mathrm{W}$ (data not shown). Other depth profiles from the area deviated from this pattern in that $V_{m}$ of peptidases declined with depth similar to, or slightly faster than bacterial abundances.

Fig. 1 suggests that bacteria react rapidly to environmental changes in the mesopelagic zone. Microbiological events in the euphotic zone, which are

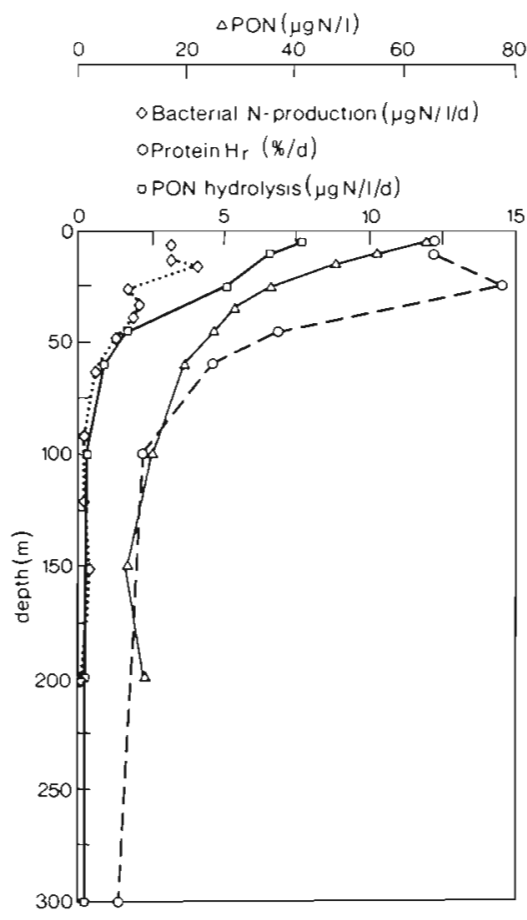

Fig. 2. Relationship between bacterial N-production and particulate organic nitrogen (PON) hydrolysis at a station $\left(46^{\circ} \mathrm{N}\right.$, $\left.18^{\circ} \mathrm{W}\right)$ in the North Atlantic. Protein hydrolysis rate $\left(H_{r}, \%\right.$ $\mathrm{d}^{-1}$ ) was estimated by the hydrolysis of the substrate analog Leu-MCA, added to the natural protein pool of the water. Mixed surface layer: $0-30 \mathrm{~m}$; subeuphotic zone: $30-100 \mathrm{~m}$; mesopelagic aphotic zone: $100-300 \mathrm{~m}$ 
fueled by nutrient inputs originating from phytoplankton, are clearly reflected by bacterial growth in the mesopelagic zone. This implies that bacteria in the mesopelagic zone, and also those being introduced into this layer by sedimentation, have the capability to respond or adapt rapidly to nutrient changes. The strength of response may depend on factors such as physical and chemical properties of sedimenting particles, residence time in the mesopelagic layer, or previous history of bacteria in the mesopelagic zone.

The relationship between hydrolysis, PON and bacterial growth was investigated at $46^{\circ} \mathrm{N}, 18^{\circ} \mathrm{W}$ (Fig. 2). Surface PON concentrations decreased to about $20 \%$ at $200 \mathrm{~m}$. Protein hydrolysis rates below $20 \mathrm{~m}$ declined faster than concentrations of PON.

Combination of measured protein hydrolysis rates with observed PON stocks at the corresponding depth

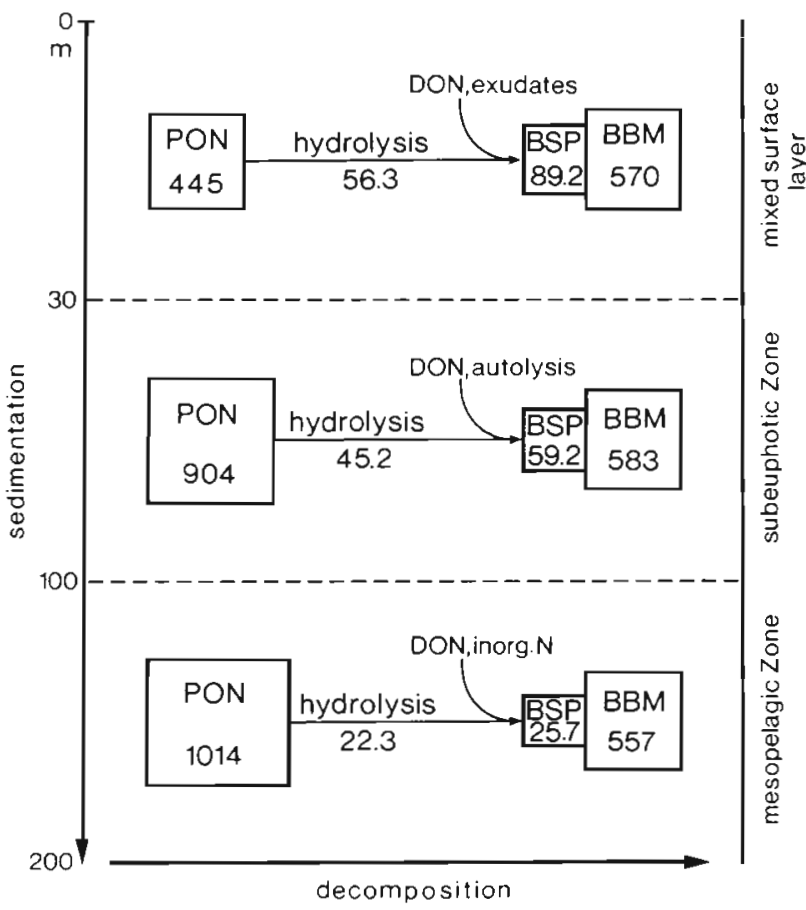

Fig. 3. Depth range integrated mass and rate balance of PONstock, PON-hydrolysis, bacterial secondary production (BSP) and bacterial biomass (BBM) in different vertical zones of a North Atlantic station $\left(46^{\circ} \mathrm{N}, 18^{\circ} \mathrm{W}\right)$. PON and BBM: mg $\mathrm{N}$ $\mathrm{m}^{-2}$, PON-hydrolysis and BSP: $\mathrm{mg} \mathrm{N} \mathrm{m} \mathrm{N}^{-2} \mathrm{~d}^{-1}$ PON has been corrected for living components by factors of $31 \%(0-50 \mathrm{~m})$, factor derived from direct observations (JGOFS 1990a), $14 \%$ $(50-100 \mathrm{~m})$ and $6 \%(100-200 \mathrm{~m})$ (Parsons et al. 1984). The balance is completed by additional pathways of PON/DON decomposition which provide substrates for BSP:PONhydrolysis products that escape direct bacterial incorporation and contribute to the ambient DON pool, and other sources like algal exudates and products of cell lysis which are important in specific compartments. These pathways support the $\mathrm{N}$ demands of BSP which are not met by PON-hydrolysis. Ratio of PON hydrolysis/BSP is 0.63 in the mixed surface layer, 0.76 in the subeuphotic zone and 0.87 in the mesopelagial provides a theoretical estimate of acutal PON hydrolysis. The assumptions on which this comparison is based are discussed below. If the products of PON hydrolysis are immediately taken up by bacteria, PON hydrolysis rates should reflect bacterial production patterns. The values of these 2 parameters were relatively close at depths adjacent to the compensation depth (48 to $92 \mathrm{~m}$ ) and even closer in the mesopelagic zone; in the zone above the thermocline, however, they differed considerably. In the latter, PON hydrolysis, as calculated here, certainly overestimates bacterial growth, because a considerable fraction of the PON is living and not prone to bacterial hydrolysis. At greater depth, PON consists mainly or exclusively of organic detritus, which is potentially prone to bacterial enzymatic hydrolysis. The correspondence between bacterial production and PON hydrolysis suggests that the growth of bacteria depends mainly on PON hydrolysis below the euphotic zone

We have calculated a mass and flux balance based on this depth profile (Fig. 3). The mass of detrital PON is $445 \mathrm{mg} \mathrm{N} \mathrm{m} \mathrm{N}^{-2}$ ( 0 to $30 \mathrm{~m}$, surface mixed layer), $904 \mathrm{mg} \mathrm{N} \mathrm{m}^{-2}$ (30 to $100 \mathrm{~m}$ ) and $1014 \mathrm{mg} \mathrm{N} \mathrm{m}^{-2}$ (100 to $200 \mathrm{~m})$; corresponding PON hydrolysis rates are 56.3. 45.2 and $22.3 \mathrm{mg} \mathrm{N} \mathrm{m}^{-2} \mathrm{~d}^{-1}$, respectively. Thus enzymatic turnover of PON is $12.7 \% \mathrm{~d}^{-1}$ in the mixed surface layer and $3.5 \% \mathrm{~d}^{-1}$ in the subeuphotic zones, which is in good agreement with other observations (Jones \& Henderson 1986). Bacterial biomass turnover (based on production/biomass ratios) is 15.6 and $7.4 \%$ $\mathrm{d}^{-1}$ in the respective zones. The discrepancy between PON turnover and bacterial biomass turnover is mainly due to differences of the corresponding pool sizes. The good agreement of PON hydrolysis and bacterial secondary production (BSP) especially in the mesopelagic zone argues for a dependency of bacterial growth on PON accessibility.

\section{DISCUSSION}

Depth-integrated detrital PON hydrolysis rates show a reasonable correspondence to bacterial secondary production (Fig. 3). PON provides an increasing fraction of bacterial production with depth, ranging from $63 \%$ in the mixed surface layer to $76 \%$ in the subeuphotic zone ( 30 to $100 \mathrm{~m}$ ) and $87 \%$ in the upper mesopelagic zone (100 to $200 \mathrm{~m}$ ). These figures add to recent observations of Smith et al. (1992) where they report on 'uncoupled' hydrolysis as a 'biochemical mechanism for large-scale transfer of organic matter from sinking particles to the dissolved phase'. Slowly degradable dissolved organic matter, the residues of bacterial substrate uptake, might then be subjected to downward export. We agree with Smith et al. (1992) 
that very little of the hydrolysate is taken up by the bacteria attached to particles (Kim 1985). But hydrolysates of aggregates of relativlely fresh particles in the mesopelagic zone should be mostly highly nutritious for bacteria and they are nearly entirely taken up by the bacteria inhabiting the water phase around the particles (which were of course included in our bacteria production measurements).

Our figures support the hypothesis of an indirect but nevertheless effective coupling of POM degradation and bacterial growth in the subeuphotic zones, however, they are subject to the following considerations: (1) If bacterial respiration determined for a protein hydrolysate to be $25 \%$ of gross uptake (Gocke 1976), is taken into account, the contribution of PON hydrolysis to bacterial secondary production reduces to $47 \%$ (mixed surface layer) and to $65 \%$ (100 to $200 \mathrm{~m}$ ). Further $\mathrm{N}$-demands for growth might be supplied by ammonia uptake (Wheeler \& Kirchman 1986) or $\mathrm{NO}_{3}$ uptake. (2) POM collected on glassfibre filters for POC/PON analysis does not necessarily include the majority of very small particles. Thus calculations of PON hydrolysis based on these conventional PON determinations may be underestimated. (3) Protein hydrolysis rates measured via substrate analogs include, a priori, detrital PON as well as DON. It is presumed that measured hydrolysis rates are valid for all types of organic $\mathrm{N}$ substrates which undergo hydrolysis, although very refractile molecules are certainly not well represented. They should not contribute substantially to organic $N$ regeneration and bacterial growth. (4) The molecular structures of PON at different depths are not known, and neither are the PON fractions which are best represented by the substrate analog. In the interpretation of our results it is presumed that these portions of PON which undergo hydrolysis are fairly constant. Relatively small changes in the $\mathrm{C}: \mathrm{N}$ ratio with depth from 5.9 to 7.2 may support this assumption. If this assumption is not true and the portion of accessible PON decreases with depth, our acutal PON hydrolysis values at depth would be too high, which may interfere with the reported congruency between bacterial growth and actual PON hydrolysis at these depth.

Alternatively, one should also consider that the relationship between the lowest added concentration of substrate analog (which is most important for the determination of the hydrolysis rate, $H_{r}$ ) and the concentration of natural PON may not be constant, as is assumed for the present calculation. In this case, added substrate analog would supply an increasing contribution to the natural PON pool at depth, which would result in an underestimation of $H_{r}$.

The 2 possible sources of error reported here might balance each other and their combined effect on actual
PON hydrolysis rates is not known. Nevertheless the tendency for increasing correspondence of PON hydrolysis and bacterial growth with depth seems to be strong enough to be taken seriously. More studies on changes of organic matter transformation with depth in the ocean are necessary to justify a generalization of statements made in the present investigation.

Measured extracellular protease activities can be attributed mainly to bacteria (Hoppe 1983, Kim 1985, Rosso \& Azam 1987), but bacterial attachment to particles, which can be recognized microscopically, is only about $5 \%$ of the total bacteria number in the mesopelagic zone. How can these few bacteria supply the $\mathrm{N}$-demands of measured total bacterial growth in the mesopelagic zone? This is one of the most puzzling paradoxes in marine microbiology. This can be looked at from the viewpoint that POM as well as bacterial attachment cannot be exactly measured and defined, because their natural configurations are changed by filtration processes. This may cause an underestimation of bacterial attachment. Bacteria clustering around slowly sinking particles (Mitchell et al. 1985) may also hydrolyse POM and be vehicles for transportation of organic matter into the water phase. Bacteria, which by chance or by chemotactic response (Jackson 1989), encounter a particle of relatively high nutritional value may reproduce faster (Pedrós-Alio \& Brock 1983, Alldredge \& Youngbluth 1985) and hydrolyse more effectively than the bulk of the attached bacteria (Karner \& Herndl 1992). On larger particles, attached bacteria may be controlled by ubiquitous protozoa (Silver et al. 1984) and POM mineralization and export of organic matter will then be mediated by a microscale microbial foodweb.

Our microbiological data from the North Atlantic indicate that bacterial extracellular hydrolysis of $\mathrm{PON}$ is a possible regulating factor of organic matter (OM) flux in the mesopelagic ocean. Even considering methodological problems, PON hydrolysis seems to correspond directly to bacterial secondary production. Smith et al. (1992) measured rapid dissolution of marine aggregates by chemical amino acid analysis. Recent observations of Cho \& Azam (1988) revealed a transformation of particulate organic matter to bacterial biomass, increasing from the euphotic mixed layer to the mesopelagic zone. Our data elucidate the 'missing link' in this process, i.e. the solubilization and recycling of $\mathrm{OM}$ by bacterial extracellular enzymatic hydrolysis of non dissolved organic matter. We agree with findings of Karl et al. (1988), that these particles must be suspended (or slowly sinking) and not rapidly sinking. The residence time (Eppley et al. 1983) of fast sinking particles in the water column would not allow for bacterial colonization (exception: fecal pellets, which bear their own microflora) and effective decom- 
position. Low densities of bacteria on particles, however, should not be confused with their hydrolytic properties. A few bacteria attached to nutritious particles, living in 'a land of milk and honey', may very well have higher enzymatic capacities than the bulk of free living bacteria (Kim 1985).

Discrepancies between rates of hydrolysis and bacterial growth in the different depth zones (Fig. 3) suggest that availability and accessibility of PON becomes a limiting factor for bacterial growth, as soon as easily degradable substrates are no longer available somewhat further below the euphotic zone. Bacterial growth in the mesopelagic zone is slow in comparison to the productive upper layer, because it depends on the relatively slow process of particle (PON) hydrolysis by attached bacteria.

Fig. 1 shows, as hypothesized from the data in Table 1, that the spatial and metabolic coupling between the euphotic zone and the mesopelagic zone will occasionally cause high bacterial activity in the latter area. These clearly visible events, however, have to be distinguished from less spectacular nutrient inputs into the mesopelagic zone, which do not give such a clear signal. Plankton bloom sedimentation is with some delay in time - also recognizable at the deep-sea sediment surface (Turley \& Lochte 1990), which suggests short residence times in the different vertical zones. In the deep-sea refractory POM of fastsinking aggregates will normally only cover the nutrient demands for the survival of the majority of bacteria (Morita 1988). Thus elevated bacterial activity in the upper mesopelagic zone im comparison to the deep sea may be due to low but more or less continuous input of slow-sinking nutritious particles from the euphotic zone.

An impact on geophysical cycles can be attributed to this 'slow' process of bacterial extracellular substrate hydrolysis. This process is the initial transformation of slowly sinking organic matter in the mesopelagic zone during the growth season. Materials cycled in this way are prevented from sinking to 'depths of no return'. Carbon and nitrogen from this pathway can subsequently reenter the photic zone in their mineralized forms, supporting new production of phytoplankton. Thus bacterial particle hydrolysis in the mesopelagic zone is a key factor for carbon and nitrogen storage and recycling in the ocean, processes, which are considered to ultimately have a major influence on the global climate (McCarthy 1989).

Acknowledgements. This work was supported by DFG grant Ho $715 / 6-1$ H. D. was supported by NSF grant OCE 8814229. We thank $C$. Stienen for unpublished PON data and $T$ Berman, K. Gocke and G. Herndl for comments on the manuscript. Skillful technical assistance was provided by $M$. Mehrens and H. L. Quinby.

\section{LITERATURE CITED}

Alldredge, A. L., Youngbluth, M. J. (1985). The significance of macroscopic aggregates (marine snow) as sites for heterotrophic bacterial production in the mesopelagic zone of the subtropical Atlantic. Deep Sea Res. 32: $1445-1456$

Alldredge, A. L., Cohen, Y. (1987). Do microscale chemical patches persist in the sea? Microelectrode study of marine snow, fecal pellets. Science 235: 689-691

Cho, B. C., Azam, F. (1988). Major role of bacteria in biogeochemical fluxes in the ocean's interior. Nature 332: $438-441$

Chróst, R. J. (1990). Microbial ectoenzymes in aquatic environments. In: Overbeck, J., Chróst, R. J. (eds.) Aquatic microbial ecology: biochemical and molecular approaches. Springer-Verlag, New York, p. $47-78$

Ducklow, H. W., Hill, S. M., Gardner, W. D. (1985). Bacterial growth and the decomposition of particulate organic carbon collected in sediment traps. Cont. Shelf Res. 4: $445-464$

Ducklow, H. W., Kirchman, D. L., Quinby, H. L., Carlson, C. A., Dam, H. G. (1993). Bacterioplankton carbon cycling during the spring bloom in the eastern North Atlantic Ocean. Deep Sea Res. 40: 245-263

Eppley, R. W., Renger, E. H., Betzer, P. R. (1983). The residence time of particulate organic carbon in the surface layer of the ocean. Deep Sea Res. 30: 311-323

Fasham, M. J. R., Ducklow, H. W., McKelvie, S. M. (1990). A nitrogen-based model of plankton dynamics in the oceanic mixed layer. J. mar. Res. 48: 591-639

Fuhrman, J. A., Azam, F. (1982). Thymidine incorporation as a measure of heterotrophic bacterioplankton production in marine surface waters: evaluation and field results. Mar. Biol. 66: 109-120

Gocke, K. (1976). Respiration von gelösten organischen Verbindungen durch natürliche Mikroorganismen-Populationen. Ein Vergleich zwischen verschiedenen Biotopen. Mar. Biol. 35: 375-383

Gordon, D. C. (1970a). A microscopic study of organic particles in the North Atlantic Ocean. Deep Sea Res. 17: $175-185$

Gordon, D. C. (1970b). Some studies on the distribution and composition of particulate organic carbon in the North Atlantic Ocean. Deep Sea Res. 17: 233-243

Gordon, D. C. (1971). Distribution of particulated organic carbon and nitrogen at an ocean station in the central Pacific. Deep Sea Res. 18: 1127-1134

Hobbie, J. E., Daley, R. J., Jasper, S. (1977). Use of Nuclepore filters for counting bacteria by fluorescence microscopy. Appl. environ. Microbiol. 33: 1225-1228

Hoppe, H.-G. (1983). Significance of exoenzymatic activities in the ecology of brackish water: measurements by means of methylumbelliferyl-substrates. Mar. Ecol. Prog. Ser. 11: 299-309

Hoppe, H.-G. (1986). Degradation in sea water. In: Rehm, U. J., Reed, G. (eds.) Biotechnology, a comprehensive treatise in 8 volumes. Vol. 8 (Schönborn, W., ed.) Verlag Chemie, Weinheim, p. 453-474

Hoppe, H.-G., Kim, S.-J., Gocke, K. (1988). Microbial decomposition in aquatic environments: a combined process of extracellular enzyme activity and substrate uptake. Appl. environ. Microbiol. 54: 784-790

Jackson, G. A. (1989). Simulation of bacterial attraction and adhesion to falling particles in an aquatic environment. Limnol. Oceanogr. 34:514-530 
JGOFS (1990a). North Atlantic bloom experiment. Report no. 4. Joint Global Ocean Flux Study office, Kiel

JGOFS (1990b). Core measurement protocols. Reports of the core measurement working groups. Report no. 6. Joint Global Ocean Flux Study office, Kie]

Jones, R., Henderson, E. W. (1986). The dynamics of nutrient regeneration and simulation studies of the nutrient cycle. J. Conseil. 43: 216-236

Jumars, P. A., Penry, D. L., Baross, J. A., Perry, M. J., Frost, B. W. (1989). Closing the microbial loop: dissolved carbon pathways to heterotrophic bacteria from incomplete ingestion, digestion and adsorption in animals. Deep Sea Res. 36: 483-495

Karl, D. M., Knauer, G. A., Martin, J. H. (1988). Downward flux of particulate organic matter in the ocean: a particle decomposition paradox. Nature 332: 438-441

Karner, M., Herndl, G. J. (1992). Extracellular enzymatical activity and secondary production in free living and marine snow associated bacteria. Mar. Biol. 113: $341-347$

Kim, S.-J. (1985). Untersuchungen zur heterotrophen Stoffaufnahme und extrazellulären Enzymaktivität von freilebenden und angehefteten Bakterien in verschiedenen Gewässerbiotopen. Dissertation, Univ. Kiel

Lee, C., Cronin, C. (1982). The vertical flux of particulate organic nitrogen in the sea: decomposition of amino acids in the Peru upwelling area and the equatorial Atlantic. J. Sea Res 40: 231-251

Lee, S., Fuhrman, J. A. (1987), Relationship between biovolume and biomass of naturally derived marine bacterioplankton. Appl. environ. Microbiol. 53: 1290-1303

McCarthy, J. J. (1989). Joint global ocean flux study. Global Change News Letter 2: 7

McCave, J. N. (1975). Vertical flux of particles in the ocean. Deep Sea Res. 22: 491-502

Mitchell, J. G., Okubo, A., Fuhrman, J. A. (1985). Microzones surrounding phytoplankton form the basis for a stratified marine microbial ecosystem. Nature 316: 58-59

This article was presented by G. Rheinheimer, Kiel, Germany
Morita, R. Y. (1988). Bioavailability of energy and its relationship to growth and starvation survival in nature. Can. J Microbiol. 34: 436-441

Parsons, T. R., Takahashi, M., Hargrave, B. (1984). Biological oceanographic processes, 3rd edn. Pergamon Press, New York, p. 330

Pedrós-Alio, C., Brock, T. D. (1983). The importance of attachment to particles for planktonic bacteria. Arch. Hydrobiol. 98: $354-379$

Rosso, A. L., Azam, F. (1987). Proteolytic activity in coastal ocean waters: depth distribution and relationship to bacterial populations. Mar. Ecol. Prog. Ser. 41. 231-240

Sasaki, H., Nishizawa, S. (1981). Vertical flux profiles in the sea off Sanriku. Mar. Ecol. Prog. Ser. 6: 191-201

Silver, M. W., Gowing, M. M., Brownlee, P. C., Corliss, J. O. (1984). Ciliated protozoa associated with oceanic sinking detritus. Nature 309: 246-247

Smith, D. C., Simon, M., Alldredge, A. L., Azam, F. (1992). Intense hydrolytic enzyme activity on marine aggregates and implications for rapid particle dissolution. Nature 359: $139-142$

Somville, M., Billen, G. (1983). A method for determining exoproteolytic activity in natural waters. Limnol. Oceanogr. 28: $190-193$

Suess, E. (1980). Particulate organic carbon flux in the oceansurface, productivity and oxygen utilization. Nature 288: $260-263$

Turley, C. M., Lochte, K. (1990). Microbial response to the input of fresh detritus to the deep-sea bed. Palaeogr. Palaeoclimatol. Palaeoecol. (Global and Planetary Section) 89: $3-23$

Wheeler, P. A., Kirchman, D. L. (1986). Utilization of inorganic and organic nitrogen by bacteria in marine systems. Limnol. Oceanogr. 3: 998-1009

Zimmermann, R. (1977). Estimation of bacterial number and biomass by epifluorescence microscopy and scanning electron microscopy. In: Rheinheimer, G. (ed.) Microbial ecology of a brackish water environment. SpringerVerlag, Berlin, p. 103-120

Manuscript first received: August 3, 1992

Revised version accepted: December 14, 1992 